Int. J. Curr. Res. Med. Sci. (2017). 3(5): 60-74

\begin{tabular}{|c|c|c|}
\hline International Journal of Current Research in & \\
Medical Sciences & \\
ISSN: 2454-5716 & \\
P-ISJN: A4372-3064, E-ISJN: A4372-3061 \\
WwW.ijcrims.com
\end{tabular}

\title{
Schiff bases: An emerging potent class of pharmaceuticals
}

\author{
Ashu Chaudhary* and Anshul Singh \\ Department of Chemistry, Kurukshetra University, Kurukshetra-136 119, India \\ *Corresponding author: Dr. Ashu Chaudhary, Assistant Professor, Department of Chemistry, \\ Kurukshetra University, Kurukshetra, Haryana, Pin- 136119, Email: ashuchaudhary21@ gmail.com,
}

\section{Abstract}

Schiff bases are the utmost extensively used organic compounds. An outsized number of Schiff bases and their complexes have been investigated for their fascinating and imperative properties. Schiff bases are significant class of compounds in medicinal and pharmaceutical fields as they have also been shown to exhibit wide-ranging biological activities, including antifungal, antibacterial, antiproliferative, anti-inflammatory, antiviral, and antitumor properties. The imine group present in such compounds has been shown to be critical to their biological activities. Metal complexes of Schiff bases are well renowned for their stability, biological activity and prospective applications in countless fields. This short review piles up with few examples of the most propitious biological active metal complexes of schiff bases.

Keywords: Antifungal, Antibacterial, Antiproliferative, Anti-inflammatory, Antiviral and Antitumor properties

\section{Graphical abstract:}

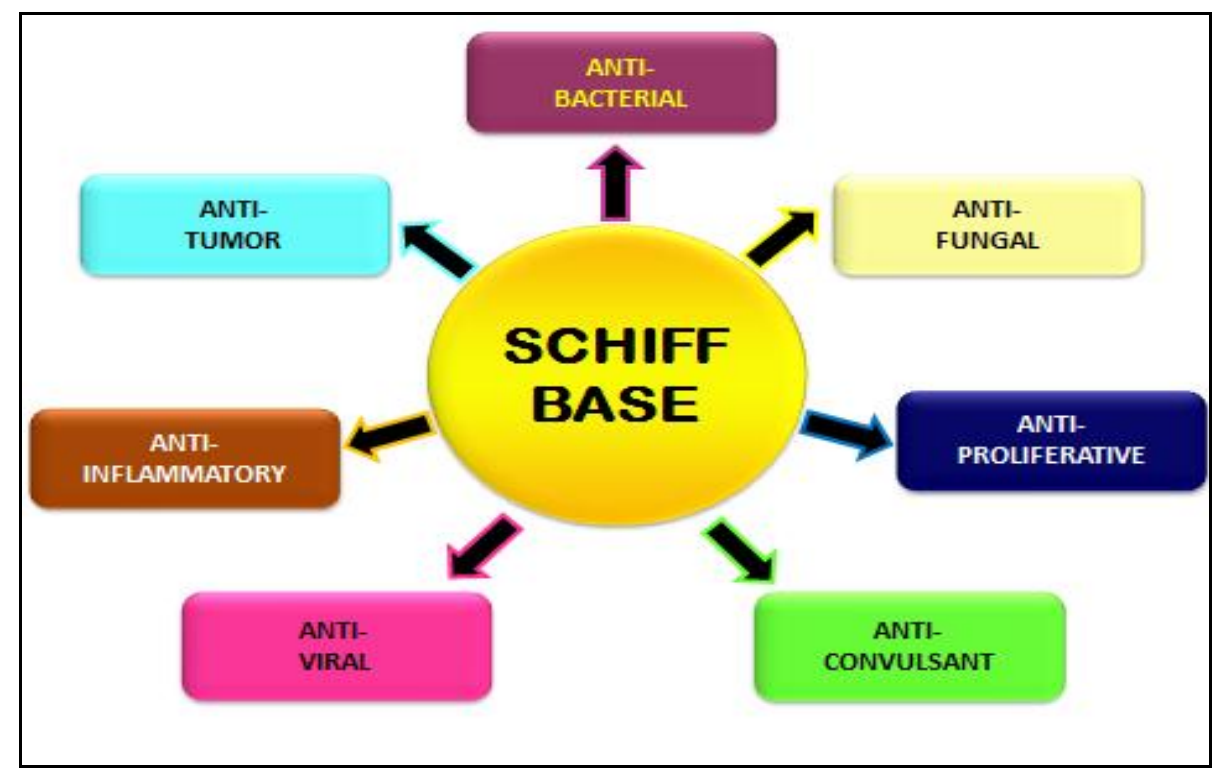




\section{Introduction}

Schiff base compounds and their metal complexes have been widely explored due to their extensive range of applications in diverse fields (Gupta et al., 2008). They are profoundly studied due to their contribution in developing complexes bearing significant biological activities as per their properties of synthetic flexibility, selectivity and sensitivity towards the central metal atom (Zoubi et al., 2013).Schiff bases having the general structure shown below played an important role in the development of coordination chemistry as they readily form stable complexes with most of the transition and non-transition metals.

$$
\mathbf{R}-\mathbf{C H}=\mathbf{N}-\mathbf{R}^{\mathbf{1}}
$$

Where: $\mathrm{R}$ and $\mathrm{R}^{1}$ are aliphatic or aromatic groups.

Schiff bases, so called since their synthesis was first reported by Hugo Schiff (Jin et al., 2005), resulted from the condensation of primary amines with aldehydes or ketones and contain a $>\mathrm{C}=\mathrm{N}$ bond. This direct reaction is the most common method of obtaining the schiff bases. Other synthetic methods have been widely reviewed by Dayagi and Degani (Dayagi et al., 1970). 2Hydroxy and 2-methoxy schiff bases and their complexes derived from the reaction of different aromatic aldehyde derivatives with diamines have been extensively studied (Yibliz et al., 1998; Kessissoglou et al., 1992).

Schiff bases and their metal complexes played a key role in our understanding of the coordination chemistry of transition metal ions. A large number of schiff base compounds are often used as chelating ligands in coordination chemistry (Shibuya et al., 2008; Roth et al., 2006) by considering their metal binding ability, useful in catalysis, medicine as antibiotics and antiinflammatory agents, and industry for anticorrosion properties (Liu et al. 2006; Bodakati et al., 2006).

The chemistry of schiff base complexes has developed rapidly in the last 30 years, solving problems related to stereochemistry and electronic factors largely governing the reactivity and stability of chelate compounds (Jin et al., 2005). The stereochemistry and electronic structure of chelates determine many properties (Nakamara et al., 1976), reactivity and ability to form adducts. These properties are important for understanding many catalytic processes and phenomena occurring in living organisms (Perrin et al., 1967). In chemistry, schiff bases are the basic units in certain dyes, whereas, some are used as liquid crystals. The rapid development of these ligands resulted in an enhanced research activity in the field of coordination chemistry leading to very interesting conclusions. Many biologically important schiff bases have been reported in the literature possessing, antibacterial (Biyala et al., 2007; Morad et al. 2007; Rajavel et al. 2008; Chohan et al., 2007) , antifungal (Rajendran et al., 2002), antimicrobial (Mishra et al., 2008), anticonvulsant (Sridhar et al., 2002), anti HIV (Sridhar et al., 2001), anti-inflammatory (Sridhar et al., 2001) and antitumor activities (Desai et al., 2001; Tarafder et al., 2002; Ren et al., 2002)

Schiff bases derived from a large number of carbonyl compounds and amines are an important class of ligands that coordinate to metal ions via azomethine nitrogen and have been studied extensively (Tumer et al., 1998). Schiff base complexes derived from 4hydroxysalicylaldehyde and amines have strong anticancer activity e.g. Ehrlich ascites carcinoma (EAC) (Zishen et al., 1993). It is well known that some drugs have increased activity when administered as metal complexes rather than as free organic compounds (Chakraborty et al., 1996). Schiff base complexes are important for designing metal complexes related to synthetic and natural oxygen carriers (Thangadurai et al., 2002).

Schiff bases and their structural analogues, as ligating compounds containing acyclic and cyclic imine $\mathrm{C}=\mathrm{N}$ bonds, are of great importance in modern coordination chemistry (Vigato et al., 2004; Garnovskii et al., 2005). Interest in metal complexes of these ligands is related to wide variability of their fine structure and obtaining of polyfunctional materials (Garnovskii et al., 1993). 
Among them, we note luminescent complexes (Mueller et al., 2006; Metelitsa et al., 2006), magnetoactive (Garnovskii et al., 2007) and liquid crystal structures (Girond-Godguin et al., 2001), chemosensors (Callan et al., 2005) and other useful metal containing azomethine compounds (Venkataraman et al., 2005). Schiff bases are important class of compounds in medicinal and pharmaceutical field. They show biological applications including antibacterial, antifungal and antitumor activity. Diaminotetradentate Schiff bases and their complexes have been used as biological models to understand the structures of biomolecules and biological processes. The interaction of metal complexes containing $\mathrm{N}_{2} \mathrm{O}_{2}$ schiff base ligands has been thoroughly considered. DNA binding is the critical step for DNA activity. The complexes make these compounds effective and stereospecific catalysts for oxidation, reduction and hydrolysis and they show biological activity, and other transformations of organic and inorganic chemistry (Shahabadi et al., 2010). It is well known that some drugs have higher activity when administered as metal complexes than as free ligands. This review deliberates the efficacy of schiff bases and their complexes in the various biological activities.

\section{Schiff base metal complexes and their applications}

Metal complexes of schiff bases represent an important class of coordination compounds (Ramesh et al., 2003; Corriu et al., 2003; Clarke, 2003). Investigations on the interaction between transition and non-transition metal complexes and DNA has attracted much interest due to the potential use of these metal complexes as chemotherapeutic drugs and tools in molecular biology. Different types of metal complexes were synthesized in order to study their abilities of recognition and cleavage toward DNA (Fang et al., 2007).

Copper(II) and nickel(II) are important life elements and play an important role in biological chemistry especially because of their interesting reactivity and catalytic activity. The copper (II) complexes derived from the schiff bases 1-[(2diethylaminoethylimino)methyl] naphthalen-2-ol and 2,4-dibromo-6-[(2-diethylaminoethylimino) methyl] phenol (Fig. 1) have been reported. (Wang et al., 2009). The urease inhibitory properties of these complexes were determined.

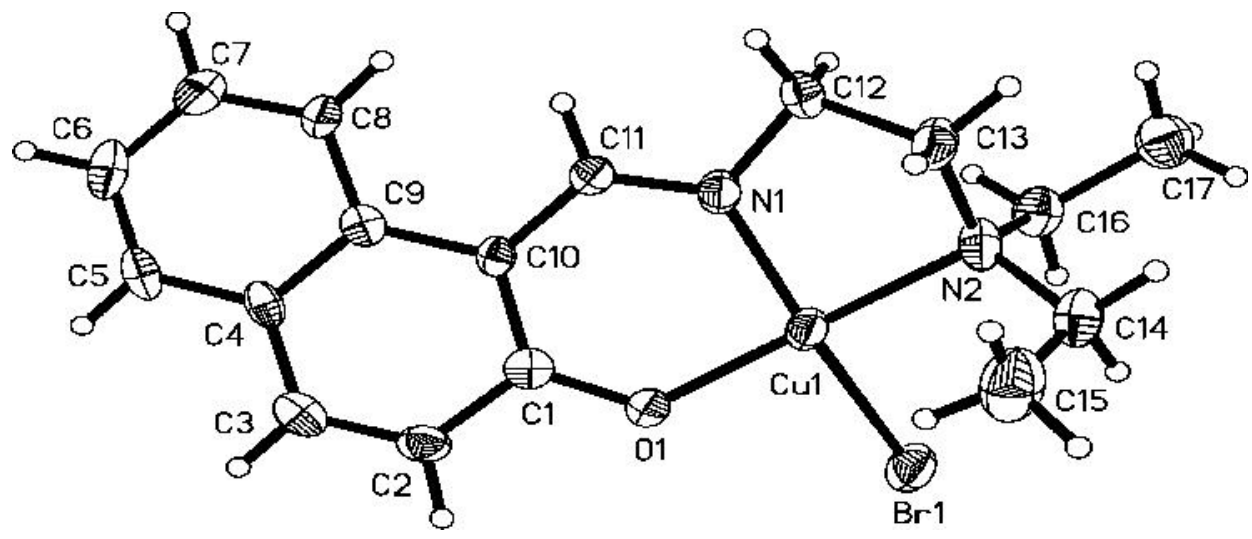

Figure 1: The structure of $\mathrm{Cu}(\mathrm{II})$ complex

Schiff bases were synthesized by the condensation of isatin with diamines (Fig. 2): ethylenediamine (HL':2IZTen), $o$-phenylene- diamine (HL":2IZTfen) or tolylene (HL"':2IZTtol) (Parnau et al., 2005). 
<smiles>O=C1Nc2ccccc2C1=NCCN=C1C(=O)Nc2ccccc21</smiles>

$\mathrm{HL}^{\prime}:$ 2IZTen<smiles>O=C1Nc2ccccc2/C1=N/c1ccccc1/N=c1/c(=O)[nH][nH]c2ccccc12</smiles>

$\mathrm{HL}^{\prime \prime}$ : 2IZTfen<smiles>O=C1Nc2ccccc2/C1=N/c1cccc(/N=c2\c(=O)[nH][nH]c3ccccc23)c1</smiles>

$\mathrm{HL}^{\prime \prime \prime}$ : 2IZTtol

Figure 2:Schiff bases synthesized by the condensation of isatin with diamines

Few monobasic bidentate schiff bases and their metal complexes were synthesized and characterized by the condensation of benzhydrazide with furfuraldehyde, 2-acetylfuran and 2-acetylthiophene (Fig. 3) and studied their antimicrobial activity (Balasubramanian et al., 2006).
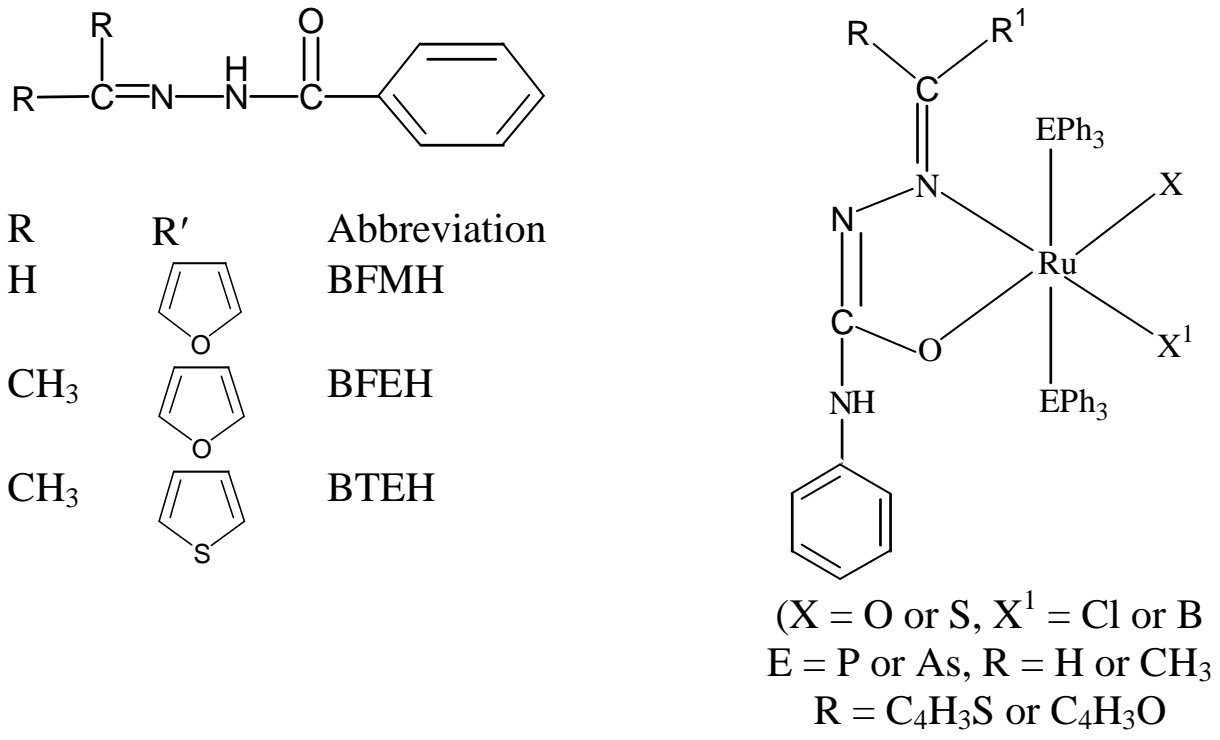

Figure 3: Monobasic bidentate schiff bases and their metal complexes 
Int. J. Curr. Res. Med. Sci. (2017). 3(5): 60-74

The metal complexes of hydrazinecarbothioamides, hydrazinecarboxamides, benzothiazolines and hydrazones schiff bases have aroused considerable interest in view of their industrial and biological interest (Gowri et al., 2010; Badwaik et al., 2009). It is well established fact that these compounds have been shown to possess antimicrobial, antitubercular (Hadda et al., 2008), antimalarial (deOliveira et al., 2008), antiviral (Singh et al., 2010) and antifertility activities (Biyala et al., 2006). The multifarious roles of transition metals in biochemistry suggest that considerable potential exists for the development of new chemistry with these metals in ligand system, specifically designed to serve these roles.

\section{Semicarbazones and their metal complexes}

It is well known that schiff base-derivatives containing $\mathrm{N}$ and $\mathrm{O}$ atoms as donor atoms can act as good chelating agents for the transition metal ions (Avaji et al., 2008). The transition metal complexes having oxygen and nitrogen donor schiff bases possess unusual configuration, structural lability and are sensitive to molecular environment (Chakraborty et al., 1996). In recent years there has been considerable attention focused on the chemistry of metal complexes of schiff bases containing nitrogen and oxygen (Karuppasamy et al., 2009; Daniel et al., 2008). Semicarbazones are usually obtained by the condensation of semicarbazide with suitable aldehyde and ketones, may be named by adding the class name 'semicarbazone' after the name of the condensed aldehyde, RCHO or ketone, $\mathrm{R}^{1} \mathrm{R}^{2} \mathrm{C}=\mathrm{O}$.<smiles></smiles>

Semicarbazide Carbonyl compound<smiles>[R]C([R])=NNC(N)=O</smiles>

\section{Semicarbazone}

Semicarbazones are versatile ligands in both the neutral and anionic forms. Although the proton lost by the anions formally belongs to the hydrazine $-\mathrm{NH}$ group, the anion is usually

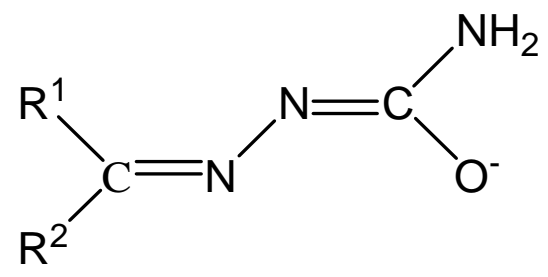

Figure 4 represented in Z-configuration (Figs. 4 and 5). It should nevertheless be borne in mind that, as in the neutral molecules, the $\pi$-charge is actually delocalized (Casas et al., 2000).

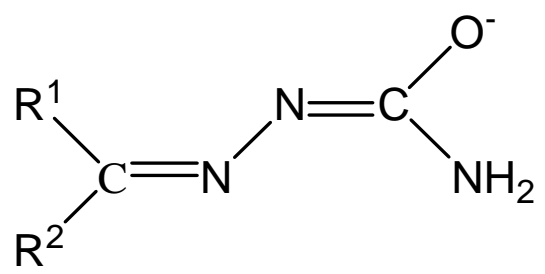

Figure 5

A linear trinuclear nickel complex was synthesized containing theligand (Fig. 6), N,N'bis(salicylidene)-1,3-diiminopropane $\left(\mathrm{H}_{2} \mathrm{Salpn}\right)$

(Yu et al., 2009). 
Int. J. Curr. Res. Med. Sci. (2017). 3(5): 60-74

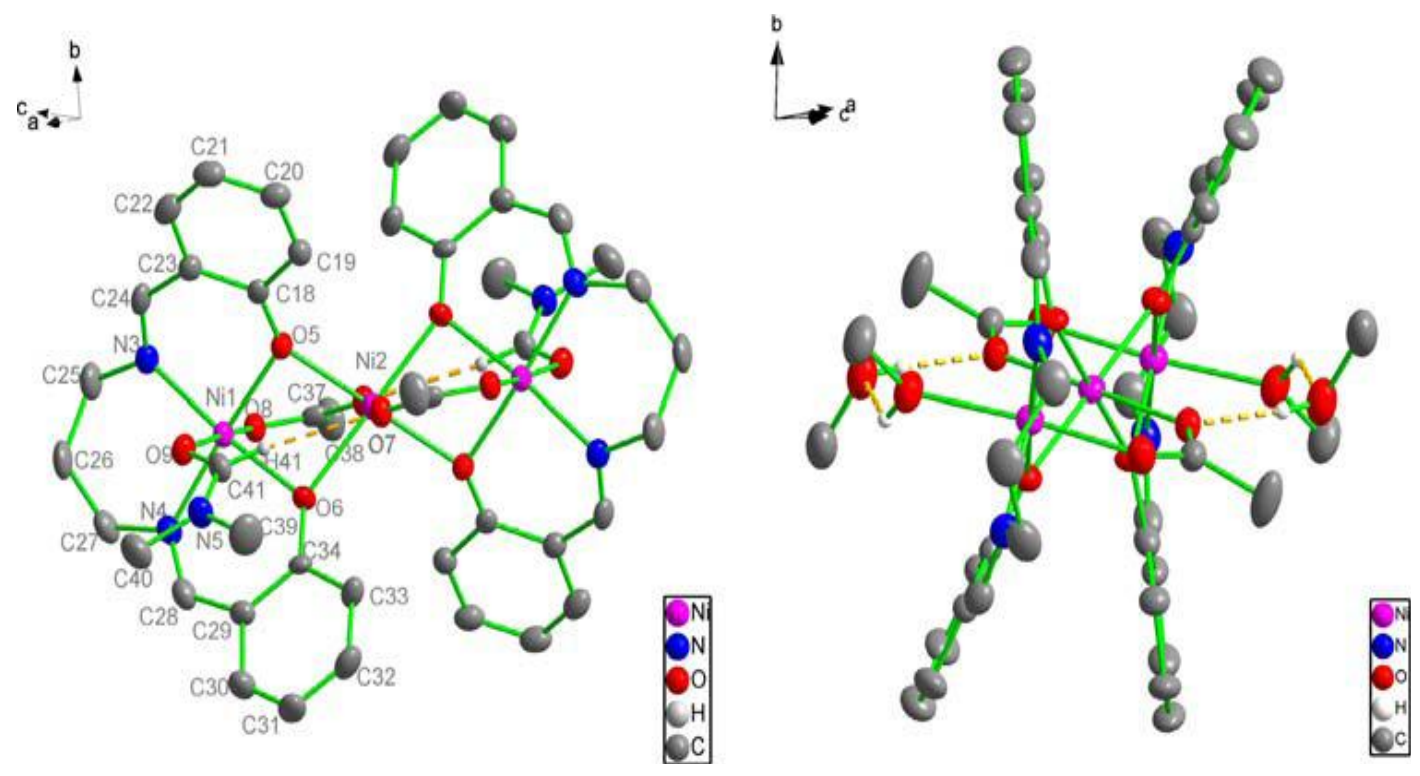

Figure 6:ORTEP diagram of the Ni(II) complex

Recently the synthesis and characterization of heterobimetallic compounds (Fig.7) were reported from semicarbazones of formylferrocene and acetylferrocene with organotin(IV) (Eugenio et al., 1999).

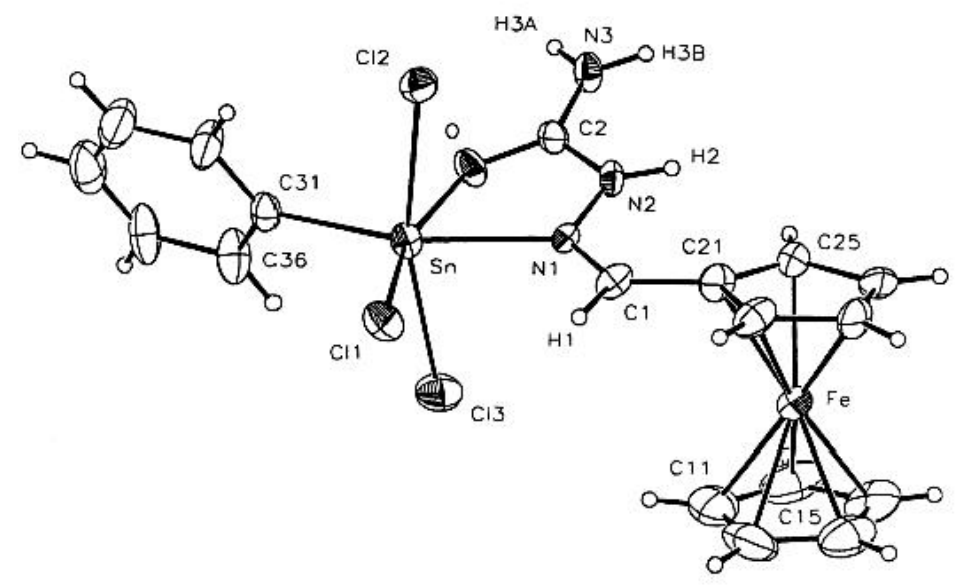

Figure 7:Heterobimetallic compounds with organotin (IV)

Pyridoxalsemicarbazone was chracterized (Fig. 8) while its metal complexes were studied for their biological activity (Leovac et al., 2005). 
Int. J. Curr. Res. Med. Sci. (2017). 3(5): 60-74

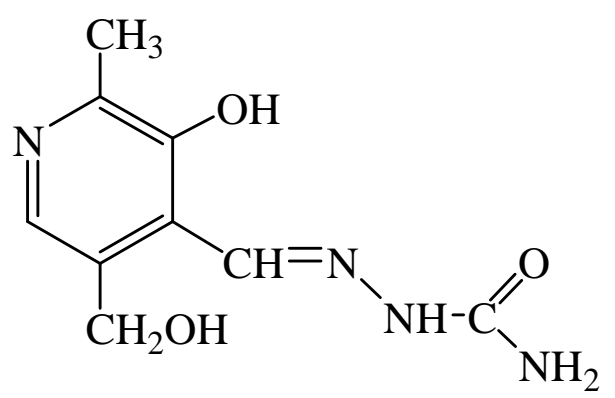

Figure 8: Pyridoxalsemicarbazone

\section{Thiosemicarbazones and their metal complexes}

Thiosemicarbazides has been studied in the past due to their mixed hard-soft donor character and versatile coordination behavior (Maji et al., 1998 and 1999). Thione compounds can act as anticarcinogenic or antitumor reagents (Ferrari et al., 2002). In their metal complexes such donor systems are able to generate novel stereochemical, electrochemical and electronic properties (Ahmed, 2006). Metal complexes of chelating agents derived from hydrazine-Smethyldithiocarboxylate and its acid amide were widely used as nitrogen-sulphur containing ligands (Nazimuddin et al., 1991).

Thiosemicarbazones possess a wide range of medical properties which have been reported by various workers to be active against tuberculosis (Domagk et al., 1946), leprosy (Lewis et al., 1959) bacterial infections (Malatesta et al., 1959), viral infections (Logan et al., 1975), psoriasis (Kaminski, 1953), rheumatism (Heilmeyer, 1950), trypanosomiasis (Wilson et al., 1974)and coccidiosis (Winkelmann et al., 1977). Thiosemicarbazones are very promising molecules in coordination chemistry because of their pharmacological properties (Zengin et al., 2006). The earliest known antivirals are thiosemicarbazones. The bioactivities of these ligands are due to the inhibition of Ribonucleotide reductase and due to complexation with essential metals (Duffy et al., 2002).
Thiosemicarbazone iron derivatives show a wide range of biological properties. It has been proposed that the cytotxicity and antitumoral activity of these compounds is related, at least in part, to the reaction of thiosemicarbazone. Iron (III) derivatives of pyridine-2-carbaldehyde thiosemicarbazone support the evidence of the reaction with thiols and subsequent formation of iron (II) species (Singh et al., 2000). However, up to date there are no crystal structures of iron (II) entities arisen from this process.

The structural diversity of thiosemicarbazide based compounds is considerably increased not only due to the condensation of the different carbonyls but also due to the alkylation of the different parts of the thiosemicarbazide moiety. While alkylation of nitrogen atoms preserves its usual coordination, through the sulphur and nitrogen atoms (Papathanasis et al., 2004), the alkylation of the sulphur atom changes the coordination to the $\mathrm{NN}$ mode, characteristic for isothiosemicarbazides (Blanchard et al., 2004).

Bis(imido) unsymmetrical multidentate Schiff base ligands were synthesized from salicylaldehyde, 5-bromosalicylaldehyde, 5nitrosalicylaldehyde and naphthaldehyde with thiosemicarbazide and their metal complexes (Fig. 9) and studied their antimicrobial activity (Yildiz et al., 2004). 
Int. J. Curr. Res. Med. Sci. (2017). 3(5): 60-74

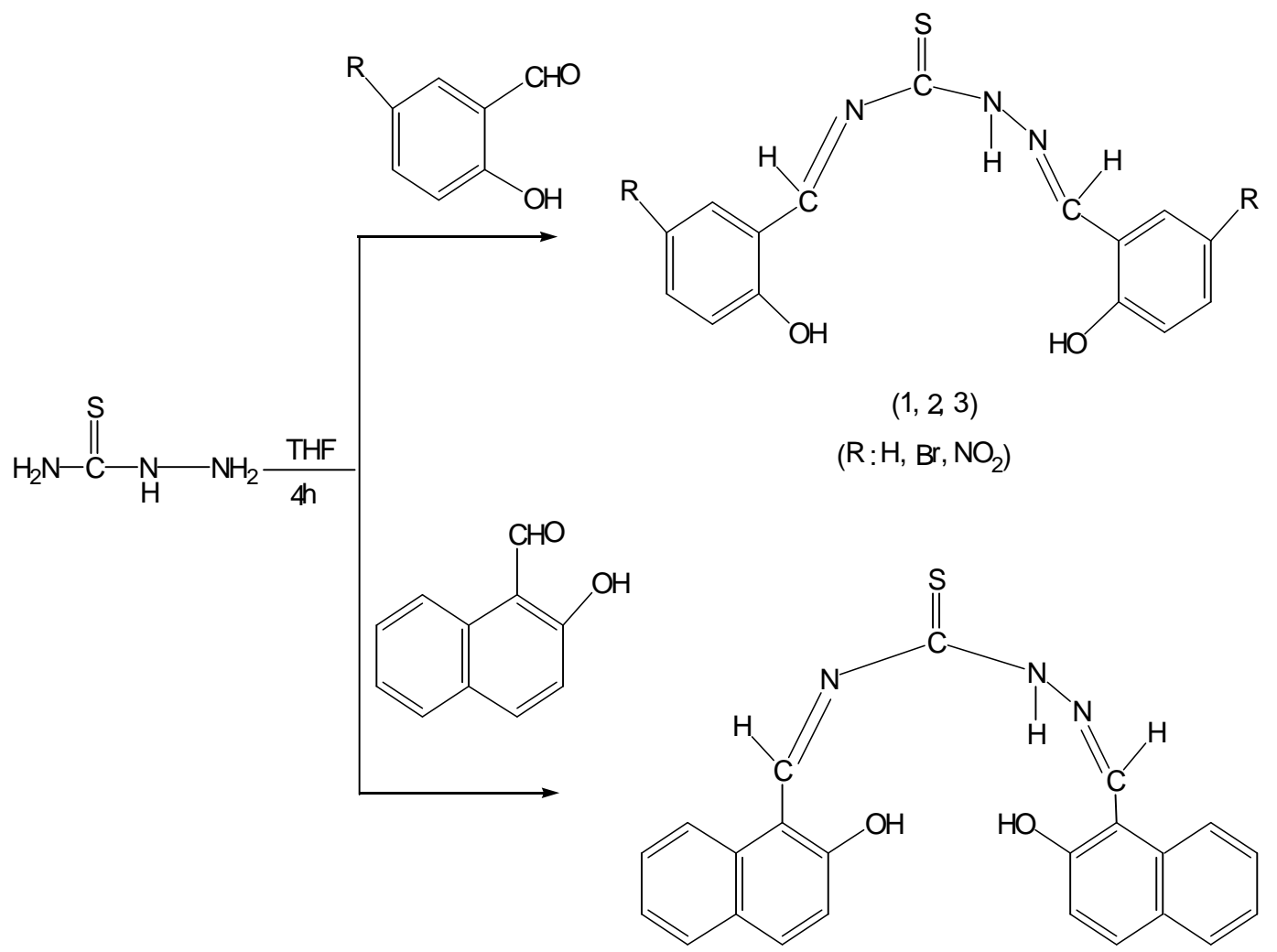

(4)

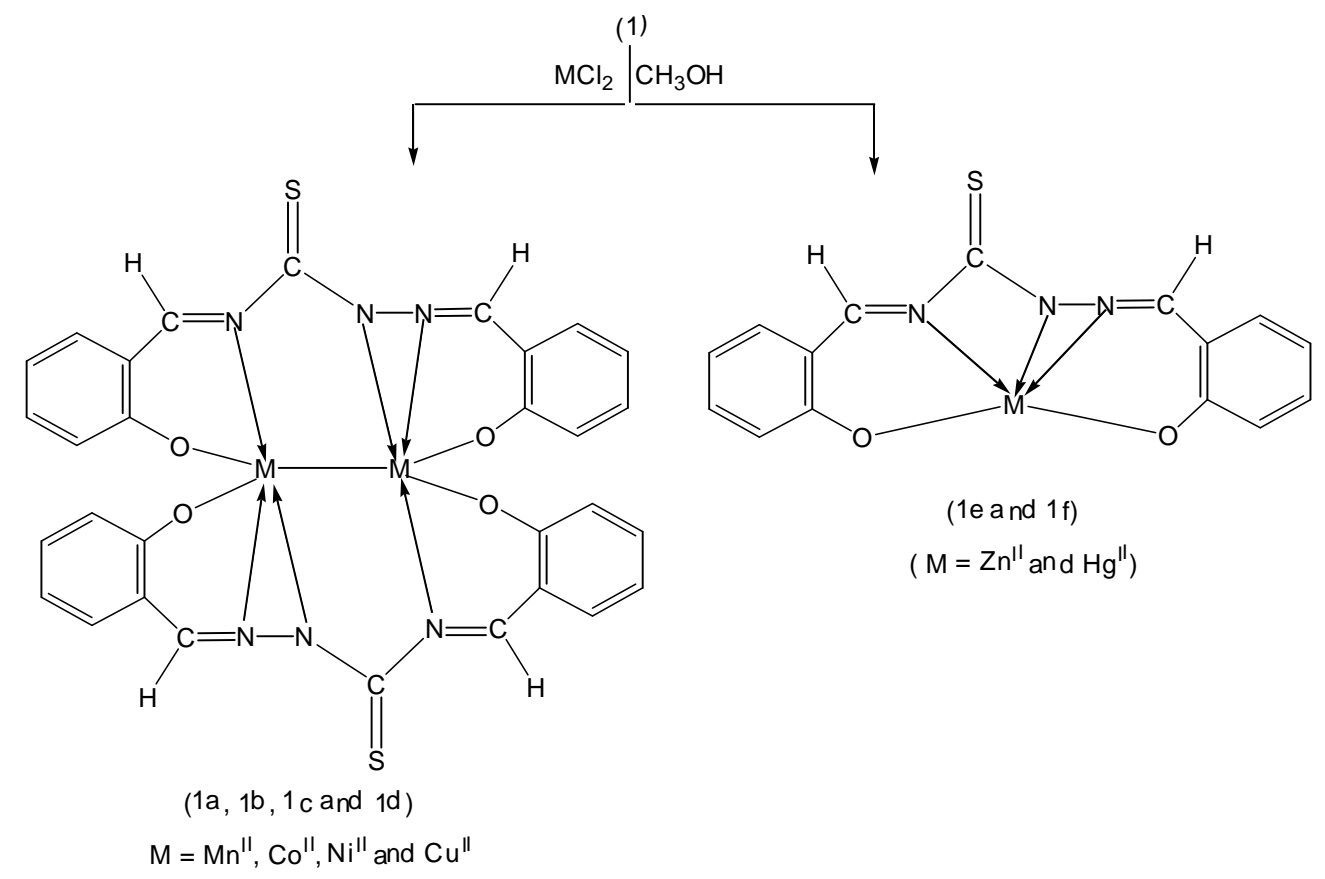

Figure 9: Bis(imido) unsymmetrical multidentateschiff base ligands.

Di-2-pyridyl ketone ${ }^{4} \mathrm{~N}$-phenyl thiosemicarbazone and its metal complexes were synthesized. The ligand and its metal complexes have also been biologically screened to show the effect on cell growth and cell proliferation in vitro on Shewanella oneidensis (Wilson et al., 2005).
A novel $\mathrm{Sn}(\mathrm{II})$ complex from pentadentate ligand bis-(4-N-methylthiosemi-carbazone)-2,6diacetylpyridine was electrochemically (Fig. 10). synthesized 


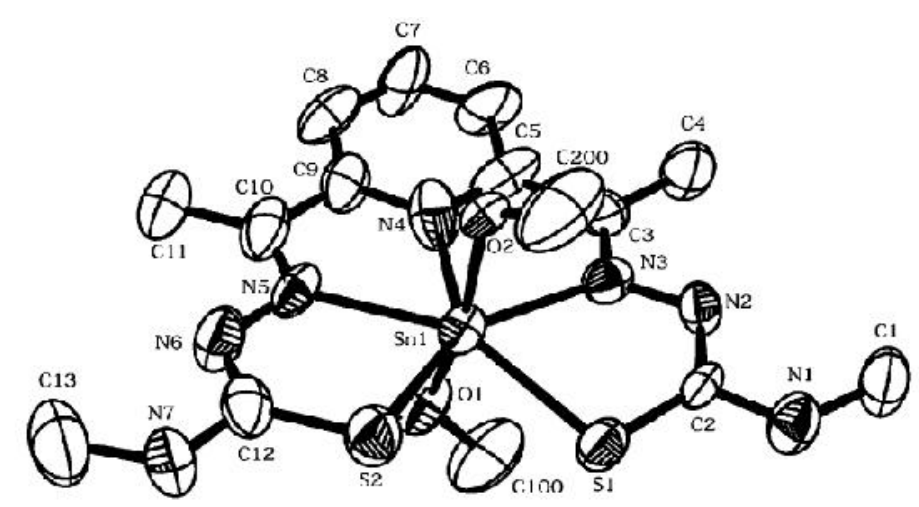

Figure 10: $\mathrm{Sn}$ (II) complex of bis-(4-N-methylthiosemicarbazone)-2,6- diacetylpyridine

\section{Dithiocarbazate and their metal complexes}

Dithiocarbazates $\mathrm{NH}_{2} \mathrm{NHCS}_{2}{ }^{-}$and their substituted derivatives have been synthesized and investigated in recent decades (Tofazzal et al., 2000). These compounds have received much attention and warrant further study because (i) they provide an interesting series of ligands whose properties can be greatly modified by<smiles>NNC(=S)S</smiles>

Figure 11:Dithiocarbazic acid

Free dithiocarbazic acid, $\mathrm{H}_{2} \mathrm{NNHCSSH}$, has been isolated (Anthoni, 1969), although its ammonium (Fig. 13) and hydrazinium (Fig. 14)<smiles>NNC(N)=S</smiles>

Figure 13:Ammoniumsalt of dithiocarbazic acid Organo-titanium (IV), tin(IV) and lead (IV) complexes with S-methyl- $\beta$-N-(2-hydroxy phenyl) methylendithiocarbazate $\left(\mathrm{H}_{2} \mathrm{SMSaD}\right)$ (Fig. 15)were also synthesized and characterized (Gopinathan et al., 1990). S-methyl- $\beta-\mathrm{N}-(2-$ introducing different organic substituents, thereby causing a variation in the ultimate donor properties, (ii) the interaction of these donors with metal ions give complexes of different geometries and properties, and (iii) these complexes are potentially biologically active. Dithiocarbazic acid (Fig. 11) is monodithiocarboxy derivative of hydrazine (Fig. 12).<smiles>N</smiles>

Figure 12:Hydrazine

salts have been known for a long time (Curtius et al., 1894).

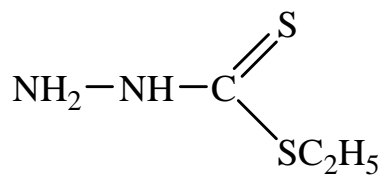

Figure 14:Hydrazinium salt of dithiocarbazic acid

hydroxy-3-methoxy-phenyl) methylendithiocarbazate $\mathrm{H}_{2} \mathrm{SMVD}$ ) (Fig. 16), 1(2-hydroxy phenyl)-2,3-diaza-4-methylthio-5thia-hexa-1,3-diene (HSSMSa) and 1-(2-hydroxy3-methoxy phenyl)-2,3-diene (HSSMV). 
Int. J. Curr. Res. Med. Sci. (2017). 3(5): 60-74<smiles>CC(=S)NNCc1ccccc1O</smiles>

Figure 15: $\mathrm{H}_{2} \mathrm{SMSaD}$<smiles>CCC(=S)NNCc1cccc(OC)c1O</smiles>

Figure 16: $\mathrm{H}_{2} \mathrm{SMVD}$
Few of the organotin (IV) complexes (Fig. 17)were also synthesized with N-methyl-Smethyl- $\beta$-N-(2-hydroxy phenyl) methylene dithiocarbazate (HNMSMSaD), N-methyl-Smethyl- $\beta$-N(2-hydroxy-1-naphthyl) methylene- dithiocarbazate (HNMSMND) and N-methyl-Smethyl- $\beta$-N-(2-hydroxy-3-methoxyphenyl) methylenedithiocarbazate (Gopinathan et al., 1993).

(HNMSMVD)<smiles>COc1cccc2c1O[In](N(C)C(C)=S)N=C2</smiles>

Figure 17: $\mathrm{Me}_{2} \mathrm{SnCl}_{2} \cdot \mathrm{HNMSMSa}$

Schiff bases derived from S-alkyl / aryl esters of dithiocarbazoic acid (Ferrari et al., 2002) have been the subjects of considerable study. The presence of hard $\mathrm{N}$ - and soft $\mathrm{S}$-donor atoms in the backbones of these ligands enable them to react readily with both transition and main group metal ions yielding stable metal complexes some of which have been shown to exhibit interesting physico-chemical properties (Liu et al., 1999) and significant biological activity. Schiff bases derived from S-alkyl / aryl-esters of dithiocarbazoic acid often act as versatile chelating agents and exhibit promising bioactivities.

A small number of transition metal complexes were synthesized and characterized with Smethylidithiocarbazate of isatin (Ali et al., 2008). Organotin(IV) complexes were also synthesized and characterized with the ligands derived from S-benzyldithiocarbazate (Fig. 18) of some heterocyclic aldehydes (Singh et al., 2006). These complexes were also reported for their good antibacterial and antifungal activities. 
Int. J. Curr. Res. Med. Sci. (2017). 3(5): 60-74
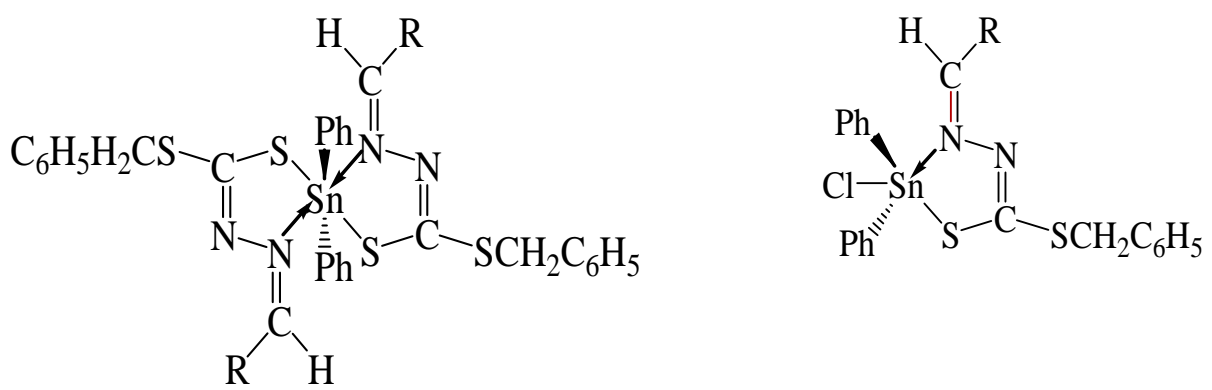

Where, R:
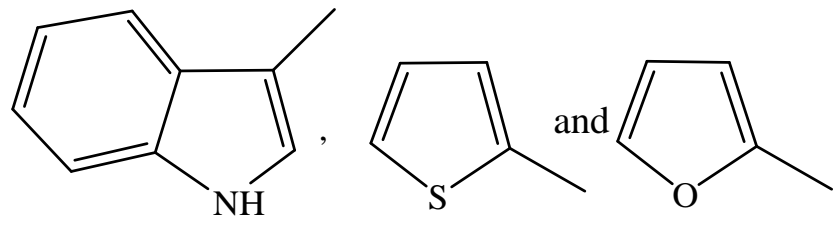

Figure 18: Organotin(IV) complexes synthesized with the ligands derived from S-benzyldithiocarbazate of some heterocyclic aldehydes.

Schiff base derived from 2-hydroxy-5- with various transition metals (Makode et al., chloroacetophenone and Smethyldithiocarbazate(Fig.19)and its coordination complexes were synthesized and characterized 2004). The antibacterial activities of the ligand and its complexes have been screened against E. coli, S. aureus, Pr. mirabilis and S. typhi.<smiles>CSC(=S)N/N=C(\C)c1cc(Cl)ccc1O</smiles>

Ketof orm

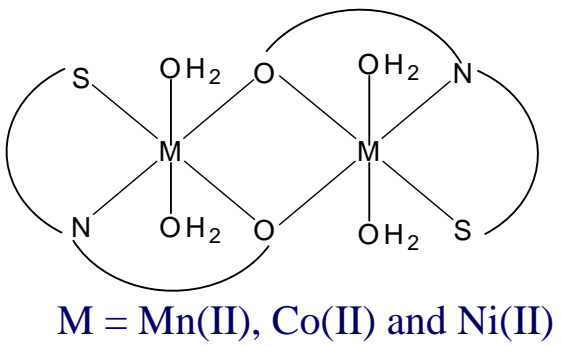<smiles>CS/C(S)=N/N=C(\C)c1cc(Cl)ccc1O</smiles>

Enolform

Figure 19: Schiff base derived from 2-hydroxy-5-chloroacetophenone and SMethyldithiocarbazate. 


\section{Isonicotinoyalhydrazone metal complexes}

Hydrazones are a versatile class of ligands that have extensive applications in various fields, possessing pronounced biological and pharmaceutical activities as antitumor (Cocco et al., 2006), antimicrobial (Vicini et al., 2002), antituberculosis (Ptole et al., 2003) and antimalarial agents (Walcourt et al., 2004). Hydrazones play an important role in improving the antitumor selectivity and toxicity profile of antitumor agents by forming drug carrier systems employing suitable carrier proteins (Kratz et al., 1998). They also have anti-inflammatory and analgesic activity equal or close to that of aspirin (Sondhi et al., 2006).

The past few decades have seen the introduction of a number of pharmaceutical compounds which contain five, six, and seven-membered rings such as piperazines, piperidines, imidazoles, benzodiazepines and other heterocycles containing nitrogen, sulphur and oxygen (Raman et al., 2009). Systems of this kind play a significant role in many biological processes due to their coordinating ability to the metal ion (Tarafder et al., 2002). Bioinorganic and biomimetics, containinga $\mathrm{C}=\mathrm{N}$ bond, are widely represented (Biyala et al., 2008). Schiff bases have been intensively investigated recently owing to their strong coordination capability and diverse biological activities, such as antibacterial and antitumor activities (Ren et al., 2002). The tuberculostatic activity of isonicotinic acid hydrazide and its aroylhydrazones containing azomethine nitrogen is attributed to their ability to form stable complexes with $d$ - and $f$-block metal ions (Pal, 2002). Interest in the study of hydrazones has been growing because of their antimicrobial, antituberculosis and antitumour activity (Bernhardt et al., 2008). Isoniazid Schiff bases have been found to show better anticancer and antitubercular activity than isoniazid (Deepa et al., 2004).

The remarkable biological activity of acid hydrazides $\mathrm{R}-\mathrm{CO}-\mathrm{NH}-\mathrm{NH}_{2}$, their corresponding aroylhydrazones $\mathrm{R}-\mathrm{CO}-\mathrm{NH}-\mathrm{N}=\mathrm{CH}-\mathrm{R}$, and the dependence of their mode of chelation with transition metal ions present in the living system have been of significant importance in the past
(Maiti et al., 1989). Chemical modification of the hydrazine unit of isoniazid with a functional group that blocks acetylation, while maintaining strong antimycobacterial action, has the potential to improve clinical outcomes and reduce the emergence in patients of acquired isoniazid resistance. Isoniazid Schiff bases and their metal complexes exhibit good antimicrobial activity than isonicotinic acid hydrazide (Kalia et al., 2007).

\section{Conclusion}

Schiff bases have been widely explored for their immense role in the medicinal field because of their pharmacological properties. In the recent years, metal complexes encompassing schiff bases have been widely studied due to their varied applications as catalysts, anti-microbial, antitumor, anti-proliferative and anti-depressant agents. Apart from this they are also used prominently in industries in the field of crystal engineering and anti-corrosion agent. Hence it is clear that there is still a long way to go, and there is further need to synthesize new metal complexes with Schiff bases having probable biological significance.

\section{Conflict of Interests}

Authors declare that there is no conflict of interests regarding publication of this work.

\section{Acknowledgements}

The authors (Ashu Chaudhary and Anshul Singh) wish to express gratitude to the Council of Scientific and Industrial Research (CSIR), New Delhi, India for financial assistance in the form of JRF vide letter no. 09/105(0221)/2015-EMR-I.

\section{References}

Ahmed, I.T. 2006.Spectrochim.Acta. 63A: 416. Ali, M.A., Bakar, H.J.H.A., Mirza, A.H., Smith, S.J., Gahan, L.R. and Bernhardt, P.V.2008.Polyhedron.27: 71.

Anthoni, U. 1969.Acta Chem. Scand. 23: 1061. Avaji, P.G., Patil, S.A. and Badami, S. 2008. Trans. Met. Chem. 33: 275. 
Badwaik, V.B., Deshmukh, R.D. and Aswar, A.S. 2009. J. Coord. Chem. 62: 2037.

Balasubramanian, K.P., Parameswari, K., Chinnusamy, V., Prabhakaran, R. and Natarajan, K. 2006. Spectrochim.Acta A. 65: 678.

Bernhardt, P.V., Wilson, G.J., Sharpe, P.C., Kalinowski, D.S. and Richardson, D.R. 2008.J. Biol. Inorg. Chem. 13: 107.

Biyala, M.K. and Singh, R.V. 2006. Phosphorus Sulfur Silicon Relat. Elem.81: 1477.

Biyala, M.K., Sharma, K., Swami, M., Fahmi, N. and Singh, R.V. 2008. Trans. Met. Chem. 33: 377.

Blanchard, S., Bill,E., Weyhermuller,T. and Wieghardt, K. 2004.Inorg. Chem. 43: 2324.

Bodakoti, A.,Abid, M. and Azam, A. 2006.Eur. J. Med. Chem. 41: 63.

Callan, J.C., da Silva, A.P. and Magir, D.C.2005.Tetrahedron.61: 8551.

Casas, J.S., Garcia-Tasende, M.S. and Sordo, J.2000.Coord. Chem. Rev. 209: 197.

Chakraborty, J. andPatel, R.N. 1996.J. Indian Chem. Soc. 73: 191.

Chohan, Z.H., Arif, M. andSarfraz,M. 2007. Appl. Organomet. Chem. 21: 294.

Clarke, A. J. 2003. Organomet. Chem. 559: 55.

Cocco, M.T., Congiv, C., Lilliu, V. and Onnis, V. 2006. Bioorg. Med. Chem. 14: 366.

Corriu, R.J.P., Lancelle-Beltran, E., Mehdi, A., Reye, C., Brandes, S. and Guilard, R. 2003.

Chem. Mater.15: 3152.

Curtius, T. and Heidenreich, K.1894.Ber.Dept. Chem. Ges.27: 55.

Daniel, V.P., Murukan, B., Kumari, B.S. and Mohanan, K.2008. Spectrochim.Acta A. 70: 403.

Dayagi, S. and Degani, Y. 1970. The Chemistry of the Carbon-Nitrogen Double Bonds, Wiley-

Interscience, New York, 71.

Deepa, K.P. and Aravindakshan, K.K.2004.Appl. Biochem. Biotech.118: 283.

de Oliveira, R.B., deSouza-Fagundes, E.M., Soares, R.P.P., Andrade, A.A., Krettli, A.U. and Zani, C.L.2008. Eur. J. Med. Chem.43: 1983.

Desai, S.B., Desai, P.B. and Desai, K.R.2001.Heterocycl.Commun.7: 83.
Domagk, G., Behnisch, R., Mietzsch, F. and Schmidt, H. 1946. Naturwissenschaften, 33: 315.

Duffy, K. J., Shaw, A.N., Delorme, E., Dillon, S.B., Miller, C.E., Giampa, L., Huang, Y., Keenan, R.M., Lamb, P., Liu, N., Miller, S.G., Price, A.T., Rosen, J., Smith, H., Wiggall, K.J., Zhang, L. and Luengo, J.J. 2002. J. Med. Chem. 45: 3573.

Eugenio, J., Graudo, J.C.,Speziali, N.L., Abras, A., Horner, M. andFilgueiras, C.A.L. 1999. Polyhedron, 18: 2483.

Fang, Y.G., Zhang, J., Cheng, S.Y., Jiang, N., Lin, H.H., Zhang, Y. and Yu, X.Q. 2007. Bioorg. Med. Chem. 15: 696.

Ferrari, M.B.,Bisceglie, F., Pelosi, G.,Albertini, M.S. and Pinelli, S. 2002. J. Inorg. Biochem.90: 113.

Ferrari, M.B., Bisceglie, F., Fava, G.G., Pelosi, G., Tarasconi, P., Albertini, R. and Pinelli, S. 2002. J. Inorg. Biochem, 89: 36.

Garnovskii, A.D.,Nivorozhkin, A.L. and Minkin, V.I.1993. Coord. Chem. Rev. 126: 1.

Garnovskii, A.D. andVasilchenko, I.S. 2005. Russ. Chem. Rev. 74: 193.

Garnovskii, A.D., Ikorskii, V.N.,Uraev, A.I.,Vasilchenko, I.S., Burlov, A.S., Garnovskii, A.D., Lyssenko, K.A., Vlasenko, V.G.,Shestakova, T.E., Koshchienko, Y.V., Kuzmenko, T.A., Divaeva, L.N.,Bubnov, M.P.,Rybalkin, V.P.,Korshunov, O.Y.,Pirog, I.V.,Borodkin, G.S., Bren, V.A.,Uflyand, I.E.,Antipin, M.Y. and Minkin, V.I.2007. J. Coord. Chem. 60: 1493.

Girond-Godguin, A.M. 2001.Coord. Chem. Rev. 1485: 216.

Gopinathan, S., Degaonkar, M.P. and Gopinathan, C.1990.Indian J. Chem. 29 A: 971.

Gopinathan, S., Degaonkar, M.P., Hundekar, A.M. and Gopinathan, C. 1993. Indian J. Chem. 32: 262.

Gowri, S., Muthukumar, M., Krishnaraj, S., Viswanathamurthi, P., Prabhakaran, R. and

Natarajan, K. 2010. J. Coord. Chem. 63: 524.

Gupta, K.C. and Sutar, A.K. 2008. Coord.Chem. Rev. 252: 1420.

Hadda, T.B., Takkurt, M., Baba, M.F., Daoudi, M., Bennani, B., Kerbal, A. and Chohan, Z.H. 2008. J. Enzyme Inhib. Med. Chem. 1: 1. 
Heilmeyer, L. 1950. Klin.Wochenschr.28: 254. Jin, V.X., Tan, S.I. and Ranford, J.D.2005.Inorg.Chim.Acta, 358: 677.

Kalia, S.B., Sharma, V., Lumba, K., Kaushal, G. and Sharma, A.2007. Indian J.Pharma. Sci. 69: 438.

Kaminski, A. 1953.Prensa Med. Argent. 40: 1263.

Karuppasamy, S., Eringathodi, S. and Mallayan, P. 2009. Inorg.Chim.Acta.362: 199.

Kessissoglou, D.P., Kirk, M.L., Lah, M.S., Li, X., Raptopoulou, C., Hatfield, W.E. and Pecoraro, V.L. 1992. Inorg. Chem. 31: 5424.

Kratz, F., Beyer, U., Roth, T., Tarasova, N., Collery, P., Lechenault, F., Cazabat, A., Schumacher, P., Unger, C. and Falken, U.1998. J. Pharm. Sci. 87: 338.

Leovac, V.M., Jevtovic, V.S., Jovanovic, L.S. and Bogdanovic, G.A. 2005. J. Serb. Chem. Soc. 70: 393.

Lewis Accinelli, A. and Quaglia, G.1959. Ann.Chim. (Rome), 49: 397.

Liu, J., Wu, B., Zhang, B. and Liu, Y.2006. Turk J. Chem. 41: 30 .

Liu, Z.H., Duan, C.Y. and Hu, J. 1999. Inorg. Chem. 38: 719.

Logan, J.C., Fox, M.P., Morgan, J.H., Makohon, A.M. and Pfau, C.J.1975. J. Gen. Virol.28: 271.

Maiti, A. and Ghosh, S. 1989. Indian J.Chem.29: 980.

Maji, M., Ghosh, S. and Chattopadhyay, S.K. 1998. Trans. Met. Chem. 23: 81.

Maji, M., Chatterjee, M., Ghosh, S., Chattopadhay, S.K., Wu, B.M. and Mark, T.C.W. 1999. J. Chem. Soc. 135.

Makode, J.T. and Aswar, A.S. 2004.Indian J. Chem. 43A: 2120.

Malatesta, P., Kolancy, J., Stimac, N.,Sajko, B., Balenovic, B. and Urbas. B. 1954. Arh.Kem.26: 71.

Metelitsa, A.V., Burlov, A.S., Bezugly, S.O., Borodkina, I.G., Bren, V.A., Garnovskii, A.D. and Minkin, V.I. 2006. Russ. J. Coord. Chem. 32: 858 .

Mishra, A.P. and Soni, M.2008. Met.Based Drugs.2008: 1.

Morad, F.M., Ajaily, M.M. and Ben Gweirif, S. 2007. J. Sci. App. 1: 72.
Mueller, K. and Schert, U. 2006. Organic Light Emitting Devices, Wiley-WCH, WeinheimNew York.

Nakamara, A. and Ryoiki, K. 1976. J. Japan. Chem. Soc. 30: 665.

Nazimuddin, M., Ali, M.A. and Smith, F.E.1991.Polyhedron.10: 1327.

Pal, S.2002. Inorg. Chem. 41: 4843.

Papathanasis, L., Demertzis, M.A., Yadav, P.N., Kovala-Demertzi, D., Prentjas, C., Castineiras,

A., Skoulika, S. and West, D.X. 2004. Inorg. Chim.Acta.357: 4113.

Parnau, C., Kriza, A., Pop, V. and Udrea, S. 2005.J. Indian Chem. Soc. 82: 71.

Patole, J., Sandbhor, U., Padhye, S., Deobagkar, D.N., Anson, C.E. and Powell, A.2003. Bioorg. Med. Chem. Lett. 13: 51.

Perrin, D.D. 1967. "Organic Analytical Reagents" Mir Moscow.

Rajavel, R., Vadivu, M.S. and Anitha, C. 2008. Eur. J. Chem., 5: 620.

Rajendran, S.P. and Karvembu, R.2002. Indian J. Chem. B. 41B: 222.

Raman, N., Johnson Raja, S. and Sakthivel, A. 2009.J. Coord. Chem. 62: 691.

Ramesh, R. and Sivagamasundari, M. 2003. Synth. React. Inorg. Met.-Org. Chem. 33: 899.

Ren, S., Wang, R., Komatsu, K., Bonaz-Krause, P., Zyrianov, Y., Mckenna, C.E., Csipke, C., Tokes, Z.A. and Lien, E.J. 2002. J. Med. Chem. 45: 410.

Roth, A., Becher, J., Herrmann, C., Gorls, H., Vaughan, G., Reiher, M., Klemm, D. and Plass, W. 2006. Inorg. Chem. 45: 10066.

Singh, A.K.,Prakash, A., Rajour, H.K., Bhojak, N. and Adhikari, D.2010.Spectrochim.Acta A,76: 376.

Singh, H.L. and Varshney, A.K.2006.Bioinorg.Chem. Appl. 2006: 1.

Singh, N.K. and Srivastava, A.2000.Trans. Met. Chem. 25: 133.

Shahabadi, N., Kashanian, S. and Darabi, F.2010.Eur. J. Med. Chem. 45: 4239.

Shibuya, Y., Nabari, K., Kondo, M., Yasue, S., Maeda, K., Uchida, F. and Kawaguchi, H. 2008. Chem. Lett. 37: 78.

Sondhi, S.M., Dinodia, M. and Kumar, A.2006.Bioorg. Med. Chem. 14: 4657. 
Sridhar, S.K., Pandeya, S.N. and De Clercq, E.2001.BollettinoChimicoFarmaceutico. 140: 302.

Sridhar, S.K. and Ramesh, A. 2001.Indian Drugs.38: 174.

Sridhar, S.K., Pandeya, S.N., Stables, J.P. and Ramesh, A. 2002. Eur. J. Pharm. Sci. 16: 129.

Tarafder, M.T.H., Kasbollah, A., Saravanan, N., Crouse, K.A., Ali, A.M. and Oo, K.T.2002.J. Biochem. Mol. Biol. Biophys. 6: 85.

Tarafder, M.T.H., Teng-Jin Khoo and Crouse, K.A.2002.Polyhedron.21: 2691.

Thangadurai, T.D., Gowri, M. and Natarajan, K. 2002.Synth. React. Inorg. Met.-Org. Chem. 32: 329.

Tofazzal, M., Tarafder, H., Ali, M.A., Saravanan, N., Weng, W.Y., Kumar, S., Tsafe, N.U. and Crouse, K.A.2000.Trans. Met. Chem. 25: 295.

Tumer, M., Erdogan, B., Koksal, H., Serin, S. and Nutku, M.Y. 1998. Synth. React. Inorg.

Met.-Org. Chem. 28: 529.

Venkataraman, N.S., Kuppuraj, G. and Rajagopal, S. 2005. Coord. Chem. Rev. 249: 1249.

Vicini, P., Zani, F., Cozzini, P. and Doytchinova, I. 2002. Eur. J. Med. Chem. 37: 553.
Vigato, P.A. and Tamburini, S. 2004. Coord. Chem. Rev. 248: 1717.

Walcourt, A.,Loyevsky, M., Lovejoy, D.B., Gordeuk, V.R. and Richardson, D.R. 2004. Int. J. Biochem. Cell Biol. 36: 401.

Wang, C.Y., Wu, X., Tu, S.J. and Jiang, B. 2009.Synth. React. Inorg.Met.-Org.Nano-Met.

Chem. 39: 78.

Wilson, B.A., Venkatraman, R., Whiteker, C. and Tillison, Q. 2005. Int. J. Environ. Res.

Public Health, 2: 170.

Wilson, H.R., Revankar, G.R. and Tolman, R.L. 1974. J. Med. Chem. 17: 760.

Winkelmann, E., Wagner, W.H. and Wirth, H. 1977. Arzneim. Forsch.27: 950.

Yildiz, M., Kilic, Z. and Hokelek, T. 1998. J. Mol. Struct. 441: 1.

Yildiz, M., Dulger, B., Koyuncu, S.Y. and Yapici, B.M. 2004. J. Indian Chem. Soc. 81: 7.

Yu, Z., He, M., Sun, P., Zhang, W. and Chang, L. 2009. J. Chem. Crystallogr. 39: 885.

Zengin, G. and Hrffman, J.W.2006.Turk. J. Chem. 30: 139.

Zishen, W., Zhiping, L. and Zhenhuan, Y.1993. Trans. Met. Chem. 18: 291.

Zoubi, W.A. 2013.Internat. J. Org. Chem. 3: 73.

\begin{tabular}{|c|l|}
\hline \multicolumn{2}{|c|}{ Access this Article in Online } \\
\hline & $\begin{array}{l}\text { Website: } \\
\text { www.ijcrims.com }\end{array}$ \\
\cline { 2 - 2 } & $\begin{array}{l}\text { Subject: } \\
\text { Pharmaceutical } \\
\text { Quick Response Code }\end{array}$ \\
\hline
\end{tabular}

How to cite this article:

Ashu Chaudhary and Anshul Singh. (2017). Schiff bases: An emerging potent class of pharmaceuticals. Int. J. Curr. Res. Med. Sci. 3(6): 60-74.

DOI: http://dx.doi.org/10.22192/ijcrms.2017.03.06.009 